\title{
KAJIAN KETERLAKSANAAN KULIAH WORKSHOP INSTALASI TENAGA LISTRIK DI TINJAU DARI KEPUASAN MAHASISWA PRODI S1 PENDIDIKAN TEKNIK ELEKTRO JURUSAN TEKNIK UNIVERSITAS NEGERI MALANG
}

\author{
Hisyam Romadhon ${ }^{1}$, Dwi Prihanto $^{2}$, dan Hari Putranto ${ }^{3}$ \\ 1,2, 3 Jurusan Teknik Elektro, Universitas Negeri Malang \\ email : romadhon.syam@gmail.com
}

\begin{abstract}
The purpose of the study was to determine the suitability of the implementation of the electric power installation workshop course in terms of the satisfaction of students of the S1 Electrical Engineering Education Study Program in the Department of Engineering, State University of Malang between the questionnaire distributed to students and the actual situation. The research method is quantitative descriptive using a questionnaire. Based on the feasibility questionnaire data obtained, the level of feasibility of the Electrical Power Installation Workshop Course Department of Electrical Engineering, State University of Malang is "very good" with a value of $95.24 \%$. In the satisfaction questionnaire obtained data, the satisfaction level of tangible aspects (tangiables) is "very satisfied", with a value of $87.30 \%$, the satisfaction level of the reliability aspect (reliability) "very satisfied", with a value of 96.83\%, the level of satisfaction aspect guarantee (assurance) is "very satisfied", with a value of $82.54 \%$, the level of satisfaction of aspects of empathy (empathy) students is "satisfied", with a value of $46.03 \%$.
\end{abstract}

Keywords: implementation, student satisfaction

\begin{abstract}
ABSTRAK
Tujuan dari penelitian adalah untuk mengetahui kesesuaian keterlaksanaan kuliah workshop instalasi tenaga listrik di tinjau dari kepuasan mahasiswa Prodi S1 Pendidikan Teknik Elektro Jurusan Teknik Universitas Negeri Malang antara angket yang disebarkan kepada mahasiswa dan keadaan sebenarnya. Metode penelitian adalah deskirptif kuantitatif dengan menggunakan kuesioner/angket. Berdasarkan data angket keterlaksanaan diperoleh, tingkat keterlaksanaan kuliah Workshop Instalasi Tenaga Listrik Jurusan Teknik Elektro Universitas Negeri Malang adalah "sangat baik" dengan nilai sebesar 95,24\%. Pada angket kepuasan diperoleh data, tingkat kepuasan aspek berwujud (tangiables) adalah "sangat puas", dengan nilai sebesar 87,30\%, tingkat kepuasan aspek kehandalan (reliability) "sangat puas", dengan nilai sebesar 96,83\%, tingkat kepuasan aspek jaminan (assurance) adalah "sangat puas", dengan nilai sebesar 82,54\%,tingkat kepuasan aspek empati (empathy) mahasiswa adalah "puas", dengan nilai sebesar 46,03\%.
\end{abstract}

Kata kunci: keterlaksanaan, kepuasan mahasiswa

\section{PENDAHULUAN}

Saat ini perguruan tinggi dituntut harus mampu mengubah sikap serta peranan dalam meberikan pelayanan. Pelayanan pendidikan pada perguruan tinggi diarahan kepada pelayanan prima, artinya memberikan pelayanan yang terbaik, maksimal, berkualitas, dengan kata lain cepat, tepat, adil, transparan, memuaskan mahasiswa serta masyarakat sesuai dengan tuntutan di era persaingan sekarang ini.

Hal ini dilakukan untuk mengetahui proses pelaksanaan kuliah yang diberikan pihak lembaga, karena sudah seharusnya hal tersebut menjadi pekerjaan bagi perguruan tinggi untuk memperbaiki kekurangan yang terdapat didalamnya dan mengetahui tingkat kepuasan mahasiswa dalam pelaksanaan kuliah yang dijalaninya. 
Kepuasan mahasiswa adalah respon mahasiswa terhadap evaluasi atau penilaian yang dirasakan setelah kegiatan perkuliahan atau norma kinerja sebelumnya sebagai perbandingan atas kinerja aktual yang dirasakan setelah suatu kegiatan selesai terlaksana. Pengukuran kepuasan pelanggan merupakan hal penting dalam menyediakan pelayanan kinerja yang baik, efektif dan efisien. Apabila pelanggan merasa puas terhadap suatu layanan yang tersedia, maka layanan tersebut dipastikan sudah efektif dan efisien.

Menurut Tjiptono (1998:35), teknik pengukuran kepuasan pelanggan dapat dilakukan dengan cara pertanyaan, responden menuliskan masalah yang dihadapi, dan responden diminta untuk merangking atau memberikan penilaian seberapa baik kinerja suatu perusahaan atau lembaga. Lupiyoadi (2001:158) menambahkan, dalam menetukan kepuasan pelanggan terdapat 5 (lima) faktor utama yang perlu diperhatikan oleh perusahaan atau lembaga, meliputi: a) kualitas produk; b) kualitas layanan; c) emosional; d) harga dan; e) biaya.

Menurut Berry dan Parasuraman dalam Alma (2005), terdapat 5 (lima) indikator kepuasan mahasiswa dalam kaitannya dangan mutu pendidikan, yaitu: a) keandalan, berhubungan dengan kebijakan pimpinan, kompetensi dosen dan pelayanan karyawan dalam memberikan pelayanan yang bermutu dengan yang dijanjikan, konsisten dan sesuai dengan kebutuhan serta harapan mahasiswa; b) ketanggapan, kesediaan personil perguruan tinggi untuk mendengarkan dan mengatasi keluhan yang dialami mahasiswa dalam perkuliahan dan yang berhubungan dengan masalah-masalah dalam studinya; c) kepastian, suatu keadaan dimana lembaga memberikan jaminan kepastian layanan kepada mahasiswa yang tidak terlepas dari kemampuan personil lembaga terutama pimpinan, dosen, karyawan untuk menimbulkan keyakinan dan kepercayaan terhadap janji-janji lembaga kepada mahasiswa disamping pelayanan yang lainnya.; d) empati, merupakan keadaan mental yang membuat seseorang merasa dirinya di keadaan orang lain. Dengan demikian bentuk empati lembaga terhadap kebutuhan mahasiswa adalah adanya pemahaman personil lembaga dan berupaya kearah pencapaiannya dan; e) berwujud, berhubungan dengan aspek fisik lembaga yang diperlukan untuk menunjang proses perkuliahan, meliputi: 1) bangunan; 2) kebersihan lingkungan; 3) laboratorium; 4) perpustakaan dan lainnya (Sopiatin, 2010).

Menurut Poerwadarminta (2005:650) kata laksana berarti sifat: tanda, laku, perbuatan. Melaksanakan berarti memperbandingkan, menyamakan, menyampaikan, melakukan, menjalankan rancangan, mempraktekkan teori dan sebagainya. Sedangkan menurut Nanang Agus Isnantoro (2009:9) mengatakan bahwa keterlaksnaan diartikan sebagai sebuah pekerjaan yang harus diselesaikan oleh seseorang untuk mencapai tujuan tertentu, baik itu diperintah oleh orang lain atau kemauannya sendiri.

Keterlaksanaan kuliah meliputi: a) kegiatan awal, diawali dari pendahuluan, apresepsi, dan memberikan motivasi; b) kegiatan inti, terdapat materi perkuliahan, strategi pembelajaran dan pengelolahan sumber belajar atau media; c) kegiatan penutup, penguatan materi dimana biasanya mahasiswa diberikan tugas pada setiap materi yang telah selesai dipelajari; d) evaluasi, kegiatan evaluasi ini bertujuan untuk menyimpulkan atau menyederhanakan baik itu materi perkuliahan, proses perkuliahan, praktikum, dan cara penyampaian materi untuk kedepannya bisa lebih ditingkatkan lagi.

Berdasarkan permasalahan tersebut peneliti bermaksud melakukan penelitian deskirptif kuantitatif dan dibuatlah angket keterlaksanaan kuliah Workshop Instalasi Tenaga Listrik dan kepuasan mahasiswa terhadap pelaksanaan kuliah untuk mengetahui kesesuaian antara angket yang disebarkan kepada mahasiswa dan keadaan sebenarnya. 


\section{METODE}

Rancangan penelitian yang digunakan menggunakan skala linkert sebagai pedoman analisis angket keterlaksanaan dan kepuasan. Tujuan digunakan skala linkert dengan empat pilihan jawaban adalah untuk menghindari kesimpangsiuran atau ketidakpastian responden dalam mengisi pertanyaan angket. Hal ini dirasa kurang efektif dikarenakan jika pilihan terdapat pilihan jawaban ganjil seperti lima pilihan jawaban maka niai tiga (3) akan menjadi simpang siur dan tidak pasti, apakah nilai tiga tersebut lebih condong ke penilaian satu dan dua atau condong ke empat atau lima.

Untuk menghindari hal tersebut, maka pada peelitian dipilihlah skala linkert dengan empat pilihan jawaban. Karena selain nilainya pasti dan akan lebih mudah dalam menganalisa data nantinya. Sebelum angket keterlaksanaan dan kepuasan diberikan kepada responden terlebih dahulu menyusun kisi-kisi dan indikator ynag akan dinilai.

Adapun rumus yang digunakan untuk mengelola data dari ahli yang mengacu pada Anas Sudijono, (2009:40) yaitu:

$$
P=\frac{F}{N} \times 100 \%
$$

Keterangan:

$\mathrm{P}=$ presentase yang dicari (frekuensi relatif)

$\mathrm{F}=$ frekuensi

$\mathrm{N}=$ jumlah responden

Sendangkan kategori penilaian kriteria acuan yang digunakan untuk mendapatkan hasil keterlaksanaan dan kepuasan dari responden mengacu pada Anas Sudijono (2009:107) yaitu:

Tabel 1. Kategori penilaian kriteria acuan

\begin{tabular}{|c|c|c|}
\hline No. & Rentang Skor (i) & Kategori \\
\hline 1. & $\begin{array}{l}\left(\begin{array}{lll}\text { Mi }+1,5 & \text { SDi } & \text { sampai } \\
\text { dengan }(\mathrm{ST})\end{array}\right.\end{array}$ & Sangat Baik \\
\hline 2. & $\begin{array}{l}(\mathrm{Mi}+0,0 \text { SDi }) \text { sampai } \\
\text { dengan }(\mathrm{Mi}+1,5 \mathrm{Sdi})\end{array}$ & Baik \\
\hline 3. & $\begin{array}{l}(\mathrm{Mi}-1,5 \mathrm{SDi}) \text { sampai } \\
\text { dengan }(\mathrm{Mi}+0,0 \mathrm{SDi})\end{array}$ & Kurang \\
\hline 4. & $\begin{array}{l}\text { (SR) sampai dengan (Mi } \\
-1,5 \mathrm{SDi})\end{array}$ & Sangat Kurang \\
\hline
\end{tabular}

Keterangan:

ST = Nilai Ideal Tertinggi

$\mathrm{SR}=$ Nilai Ideal Terendah

$\mathrm{Mi}=$ Rata-Rata Ideal $=1 / 2 \times(\mathrm{ST}+\mathrm{SR})$

$\mathrm{SDi}=$ Standar Deviasi Ideal $=1 / 6 \times(\mathrm{ST}-\mathrm{SR})$

\section{HASIL DAN PEMBAHASAN}

Penelitian ini merupakan penelitian deskriptif kuantitatif, metode yang digunakan pada penelitian ini dalah survei dengan teknik pengumpulan data menggunakan angket. Menurut M. Iqbal Hasan (2002:13) menjelaskan, penelitian deskirptif adalah mempelajari masalah-masalah dalam masyarakat, tata cara yang berlaku dalam masyarakat serta situasi-situasi termasuk tentang hubungan, kegiatan-kegiatan, sikapsikap, pandangan, serta proses-proses yang sedang berlangsung dan pengaruh-pengaruh dari suatu fenomena.

Dari angket yang disebar kepada responden, responden yang dimaksud dalam penelitian ini adalah mahasiswa S1 Pendidikan Teknik Elektro angkata 2016 yang berjumlah 63 mahasiswa. Pada subjek keterlaksanaan dari 30 butir pertanyaan angket diperoleh skor terendah (minimum) 92, skor tertinggi (maximum) 120, rerata (mean) 108.02, nilai tengah (median) 105, nilai yang sering muncul (mode) 104, standar deviasi (Sdi) 7,09.

Kemudian dianalisa sehingga didapatkan hasil dari keterlaksanaan itu sendiri, bahwa tingkat keterlaksanaan kuliah Workshop Instalasi Tenaga Listrik Jurusan Teknik Elektro Universitas Negeri Malang adalah "sangat baik" dengan nilai sebesar 95,24\%, "baik" $4,76 \%$, "tidak baik" $0.00 \%$, dan "sangat tidak baik" $0,00 \%$. Maka dapat dikategorikan bahwa tingkat keterlaksanaan kuliah Workshop Instalasi Tenaga Listrik Jurusan Teknik Elektro Universitas Negeri Malang adalah "Sangat Baik”.

Begitu juga dengan kepuasan, dari total 44 butir pertanyaan yang diberikan dan pertanyaan tersebut dipilah untuk disesuaikan dengan indikator-indikator kepuasan tersebut. 
Diketahui bahwa pada kepuasan berwujud dengan total 10 butir pertanyaan diperoleh data dari 63 mahasiswa sebagai responden skor terendah (minimum) 30, skor tertinggi (maximal) 40, rerata (mean) 35,29, standar deviasi (SDi) 2,60, nilai yang sering muncul (mode) 35, dan nilai tengah (median) 35. Kemudian data tersebut dianalisa sehingga diperoleh hasil bahwa tingkat kepuasan aspek berwujud (tangiables) adalah "sangat puas" dengan nilai sebesar 87,30\%, "puas" $12,70 \%$, "tidak puas" $0.00 \%$, dan "sangat tidak puas" $0,00 \%$. Maka dapat dikategorikan bahwa tingkat kepuasan berwujud (tangiables) mahasiswa pada kuliah Workshop Instalasi Tenaga Listrik Jurusan Teknik Elektro Universitas Negeri Malang adalah "Sangat Puas".

Diketahui bahwa pada kepuasan kehandalan (reliability) diperoleh data dari 63 mahasiswa sebagai responden skor terendah (minimum) 35, skor tertinggi (maximal) 44, rerata (mean) 39,65, standar deviasi (SDi) 2,42, nilai yang sering muncul (mode) 41, dan nilai tengah (median) 40. Kemudian data tersebut dianalisa sehingga hasil yang diperoleh bahwa tingkat kepuasan aspek kehandalan (reliability) adalah "sangat puas" dengan nilai sebesar 96,83\%, "puas" $3,17 \%$, "tidak puas" $0.00 \%$, dan "sangat tidak puas" $0,00 \%$. Maka dapat dikategorikan bahwa tingkat kepuasan kehandalan (reliability) mahasiswa pada kuliah Workshop Instalasi Tenaga Listrik Jurusan Teknik Elektro Universitas Negeri Malang adalah "Sangat Puas".

Diketahui bahwa pada kepuasan ketanggapan (responsibility) diperoleh data dari 63 mahasiswa sebagai responden skor terendah (minimum) 20, skor tertinggi (maximal) 28, rerata (mean) 25,14, standar deviasi (SDi) 2,13, nilai yang sering muncul (mode) 25 , dan nilai tengah (median) 25.

Kemudian data dinalisa sehingga hasil yang diperoleh bahwa tingkat kepuasan ketanggapan (responsiveness) adalah "sangat puas" dengan nilai sebesar $88,89 \%$, "puas"
$11,11 \%$, "tidak puas" $0.00 \%$, dan "sangat tidak puas" $0,00 \%$. Maka dapat dikategorikan bahwa tingkat kepuasan ketanggapan (responsiveness) mahasiswa pada kuliah Workshop Instalasi Tenaga Listrik Jurusan Teknik Elektro Universitas Negeri Malang adalah "Sangat Puas".

Diketahui bahwa pada kepuaasan jaminan (assurance) diperoleh data dari 63 mahasiswa sebagai responden skor terendah (minimum) 32, skor tertinggi (maximal) 44, rerata (mean) 39,17, standar deviasi (SDi) 3,46, nilai yang sering muncul (mode) 39,17, dan nilai tengah (median) 39. Kemudian data dianalisa sehingga hasil yang diperoleh bahwa tingkat kepuasan aspek jaminan (assurance) adalah "sangat puas" dengan nilai sebesar $82,54 \%$, "puas" $17,46 \%$, "tidak puas" $0.00 \%$, dan "sangat tidak puas" $0,00 \%$. Maka dapat dikategorikan bahwa tingkat kepuasan jaminan (assurance) mahasiswa pada kuliah Workshop Instalasi Tenaga Listrik Jurusan Teknik Elektro Universitas Negeri Malang adalah "Sangat Puas".

Diketahui bahwa pada kepuasan empati (empathy) diperoleh data dari 63 mahasiswa sebagai responden skor terendah (minimum) 14, skor tertinggi (maximal) 20, rerata (mean) 15,56, standar deviasi (SDi) 1,57, nilai yang sering muncul (mode) 15, dan nilai tengah (median) 16. Kemudian data dianalisa sehingga hasil yang diperoleh bahwa tingkat kepuasan aspek empati (empathy) adalah "sangat puas" dengan nilai sebesar 46,03\%, "puas" 53,97\%, "tidak puas" $0.00 \%$, dan "sangat tidak puas" $0,00 \%$. Maka dapat dikategorikan bahwa tingkat kepuasan empati (empathy) mahasiswa pada kuliah Workshop Instalasi Tenaga Listrik Jurusan Teknik Elektro Universitas Negeri Malang adalah "Puas"

\section{SIMPULAN}

Keterlaksanaan kuliah Workshop Instalasi Tenaga Listrik Universitas Negeri Malang dikatakan sangat baik, dosen dan laboran dinilai berkompeten dalam 
melaksanakan perkuliahan ini. Kepuasan mahasiswa terhadap perkuliahan Workshop Instalasi Tenaga Listrik secara keseluruhan dikatakan sangat baik, namun karena kepuasan itu sendiri terdiri dari beberapa sub variabel maka dari itu satu per satu sub variabelnya dianalisa kembali.

Diperlukan inspeksi atau pengecekkan berkala bagi jurusan pada ruang kuliah terutama laboratorium untuk kenyamanan, kemudahan dan kelancaran kuliah. Terutama pada laboratorium perlu adanya monitoring peralatan dan komponen praktikum yang tersedia serta memadai.

\section{DAFTAR RUJUKAN}

Anas Sudijono. (2009). Pengantar Statistik Pendidikan. Jakarta: PT Raja Grafindo Persada.

Arikunto, S. 2010. Dasar-Dasar Evaluasi Penelitian. Jakarta: Rineka Cipta.
J. Supranto. (2006). Tingkat Kepuasan Pelanggan. Cetakan Pengukuran Ketiga Rineka Cipta Jakarta Anas Sudijono. (2009). Pengantar Statistik Pendidikan. Jakarta: PT Raja Grafindo Persada.

Rommy, Sidharta. (2014). "Tingkat Kepuasan Peserta Didik Terhadap Sarana dan Prasarana Pendidikan Jasmani di SD Gendengan, Kecamatan Seyegan, Kabupaten Sleman. Skripsi. Fakultas Ilmu Keolahragaan Unversitas Negeri Yogyakarta.

Sugiyono. (2007). Metode Penelitian Kuantitatif Kualitatif dan $R \& D$. Bandung Alfabeta.

Universitas Negeri Malang. 2018. Pedoman Penulisan Karya Ilmiah (Edisi Kelima). Malang: Universitas Negeri malang. 